\title{
Stavovi o cjelovitoj seksualnoj edukaciji u hrvatskim školama: rezultati nacionalnog istraživanja mladih
}

\author{
Jegor MODRIĆ \\ Zagreb \\ jegor.modric@gmail.com \\ Damir ŠOH \\ Odjel za sociologiju Hrvatskih studija Sveučilišta u Zagrebu \\ Aleksandar ŠTULHOFER \\ Odsjek za sociologiju Filozofskog fakulteta Sveučilišta u Zagrebu
}

\begin{abstract}
Cilj ovoga rada bio je ispitati stavove mladih o potrebi uvođenja seksualne edukacije u hrvatske škole, profilu osoba koje bi trebale izvoditi takav program te stupanj prihvaćanja 11 tema karakterističnih za tzv. cjelovitu seksualnu edukaciju. Istraživanje, izvorno posvećeno rizicima HIV-a, provedeno je metodom ankete u veljači 2010. godine na stratificiranom nacionalnom uzorku osoba $u$ dobi od 18 do 25 godina $(\mathrm{N}=1005)$. Većina sudionika $(83,8 \%)$ je bila mišljenja kako bi »seksualni odgoj i edukaciju« trebalo uvesti u hrvatske škole. Kao idealnu osobu za izvođenje programa naveli su liječnika/cu (36,9\%), odnosno vršnjake edukatore $(23 \%)$. Niti jedna od 11 ponuđenih tema cjelovite seksualne edukacije, izvedenih iz nedavno objavljenih UNESCO-vih Međunarodnih smjernica za seksualnu edukaciju, nije ocijenjena nevažnom. Najvažnijima su procijenjene teme Spolno prenosive bolesti i zaštita, Seksualno uznemiravanje i zlostavljanje te Trudnoća i roditeljstvo. Ukupna prosječna ocjena za svih 11 tema iznosila je 3,26 $(\mathrm{SD}=0,46$; teorijski raspon $=1-4)$. Premda su utvrđene spolne razlike u prihvaćanju nekih tema, rangiranje tri najprihvaćenije, odnosno najmanje prihvaćene tematske jedinice nije se pokazalo spolno specifičnim. Izrazito religiozni i nereligiozni sudionici vrlo malo su se razlikovali u ocjeni važnosti i rangiranju ponuđenih tema. U cjelini, nalazi upućuju na to da bi većina mladih u Hrvatskoj mogla biti sklona istoj ili vrlo sličnoj koncepciji seksualne edukacije u školama.
\end{abstract}

Ključne riječi: seksualna edukacija, cjelovita seksualna edukacija, mladi, škola, UNESCO-ve smjernice za seksualnu edukaciju, religioznost 


\section{Uvod}

Programi seksualne edukacije u školama (dalje u tekstu SE) imaju za zadatak pomoći mladim ljudima pribaviti relevantne informacije o ljudskoj seksualnosti i razviti vještine potrebne za očuvanje seksualnog i reproduktivnog zdravlja. Kao što su evaluacijske studije pokazale, neki programi SE doista unaprjeđuju informiranost i odgovorno seksualno ponašanje (Grunseit i Kippax, 1997; Kirby i dr., 2007). Općenito gledajući, razlikujemo dvije dominantne vrste SE: apstinencijske (abstinence-only) i cjelovite (comprehensive) programe. ${ }^{1}$ Apstinencijski programi su usredotočeni na odgađanje seksualnih aktivnosti do ulaska u trajnu monogamnu vezu, odnosno brak (Donovan, 1998). S druge strane, programi cjelovite SE imaju širi raspon ciljeva, pri čemu je zajednički nazivnik naglašavanje pozitivnih aspekata seksualnosti. Cjelovita SE u pravilu uključuje tri edukacijske dimenzije: upoznavanje s pouzdanim (znanstveno provjerenim) informacijama, usvajanje vještina potrebnih za minimiziranje rizika vezanih uz seksualno ponašanje $i$ promoviranje pozitivnih stavova prema seksualnosti, spolne/ rodne ravnopravnosti te tolerancije prema seksualnim manjinama (Council of Representatives, 2005; Constantine, Jerman i Huang, 2007; Hodžić i Štulhofer, 2002).

Apstinencijski programi SE su najrašireniji u Sjedinjenim Američkim Državama (SAD), gdje ih podržavaju društvene organizacije i skupine koje karakterizira zastupanje tradicionalnih vrijednosti, konzervativna politička ideologija te povezanost s vjerskim organizacijama (Bleakley, Hennessy i Fishbein, 2010). Programi cjelovite SE osobito su prisutni na sjeveru Zapadne Europe, u zemljama poput Nizozemske i Švedske (Hodžić i Štulhofer, 2002; Wellings i Parker, 2006). U tim zemljama, cjelovita se SE temelji na dugoj tradiciji liberalne demokracije i religijskog pluralizma, što se odražava u izostanku izravnog utjecaja crkvenih organizacija na njihovo kreiranje (Wellings i Parker, 2006).

Uvođenje i zagovaranje pojedinog programa SE često dovodi do ideoloških sukoba, tzv. kulturnih ratova, osobito žestokih u SAD-u (Irvine, 2000; Klein, 2006). U posljednjih petnaestak godina, javni i znanstveni diskurs o programima SE poglavito je bio usmjeren na učinkovitost apstinencijskih programa (Bleakley, Hennessy i Fishbein, 2010). Premda su dosadašnja istraživanja pokazala da programi koji se temelje na odgađanju seksualne aktivnosti do ulaska u trajnu i monogamnu vezu ne uspijevaju ispuniti postavljene ciljeve (ne odgađaju seksualnu inicijaciju, niti rezulti-

\footnotetext{
${ }^{1}$ Programi cjelovite seksualne edukacije u nas se katkad nazivaju i sustavnom seksualnom edukacijom (usp. Hodžić i Štulhofer, 2002).
} 
raju prestankom seksualnih aktivnosti kod seksualno aktivnih mladih ljudi; Grunseit i Kippax, 1997; Kirby, 1999; Underhill, Montgomery i Operario, 2007; Kohler, Manhart i Lafferty, 2008), potpora njihovu izvođenju u školama je i dalje snažna, poglavito u SAD-u.

Usprkos ranim pokušajima sedamdesetih godina 20. stoljeća (usp. Cotić i dr., 1973; Maleš, 2000), u Hrvatskoj se pitanje SE tek nedavno aktualiziralo. Godine 2004. Ministarstvo znanosti, obrazovanja i športa (MZOŠ) pokrenulo je analizu izvannastavnih programa SE, što je obnovilo i intenziviralo rasprave o potrebi uvođenja SE u osnovne i srednje škole (Bijelić, 2008). U to vrijeme, u Hrvatskoj su postojala dva programa SE, Teen Star i MEMOAIDS. Prvi od njih je apstinencijski program razvijen u SAD-u koji je, uz potporu Katoličke crkve, promovirala istoimena civilna udruga. Lobiranje za uvođenje programa u redovitu nastavu (MZOŠ ga je odobrio kao izvannastavni, izborni sadržaj) isticalo je da program pruža cjelovit odgoj i izgradnju osobnosti promicanjem ideje da brak, kao jedini potpuno predan odnos između muškarca i žene, predstavlja jedini zdrav i moralno prihvatljiv okvir za seksualnu aktivnost (Pavlović, 2004). Uredi Pravobraniteljice za djecu i Pravobraniteljice za ravnopravnost spolova zaprimili su brojne pritužbe nevladinih organizacija prema kojima spomenuti program krši Ustav i zakone RH, točnije Zakon o jednakopravnosti spolova, Zakon o istospolnim zajednicama te Konvenciju o pravima djeteta (Bijelić, 2008).

Program MEMOAIDS, koji postoji od kraja devedesetih godina, program je vršnjačke edukacije u cilju prevencije HIV-a (Hiršl-Hećej i dr., 2006). Program su podržali Ministarstvo zdravstva i MZOŠ, ali je 2004. godine doživio oštre kritike Hrvatske biskupske konferencije, što je imalo za posljedicu odustajanje dijela srednjih škola od sudjelovanja u programu evaluacije financiranom od strane Globalnog fonda za borbu protiv malarije, tuberkuloze i HIV/AIDS-a (Bijelić, 2008; Hiršl-Hećej i dr., 2006).

Niti jedan od navedenih programa nije dobio potporu komisije MZOŠa za uvođenje u nastavni plan i program, pri čemu su sukobi unutar same komisije rezultirali prijedlogom da se umjesto SE u škole uvede širi i obuhvatniji program Zdravstvenog odgoja (dalje u tekstu ZO). U tu svrhu formirano je novo stručno povjerenstvo koje je, nakon brojnih formalnih i neformalnih rasprava $\mathrm{s}$ autorima prijedloga te nekoliko glasovanja, ${ }^{2}$ predložilo eksperimentalno provođenje dvaju programa ZO u srednjim i jednog u osnovnim školama. Oba su programa, uz ostale sadržaje, uključivala i modul posvećen ljudskoj seksualnosti.

\footnotetext{
${ }^{2}$ Posljednji autor rada sudjelovao je u radu spomenutog Povjerenstva.
} 
U prvom od dvaju programa, koji je predložila udruga GROZD, modul SE temelji se na apstinencijskom pristupu Teen Stara. Pravobraniteljstva su i ovoga puta kritizirala elemente modula navodeći da promiče netoleranciju prema seksualnim manjinama i zanemaruje spolnu/rodnu ravnopravnost (Bijelić, 2008). Modul SE u drugom izabranom programu, čiji je predlagač bila udruga Forum za slobodu odgoja, također je razvijen u SAD-u i to u sklopu programa financiranog od Instituta Otvoreno društvo (FlahertyZonis, 2001). Za razliku od modula udruge GROZD, ovaj modul sadržajno odgovara cjelovitoj SE. Oba su programa ZO nedavno testirana u 27 osnovnih i srednjih škola u Hrvatskoj, pri čemu je korišten eksperimentalni nacrt (Izvještaj o provedbi..., 2008). ${ }^{3}$ Nakon što provedena evaluacija nije pokazala značajne efekte programa - mjerena je isključivo dimenzija informiranosti - MZOŠ je objavio kako odustaje od uvođenja ZO u ionako preopterećene školske programe. Pritom je naglašeno da su sadržaji vezani uz ljudsku spolnost već dovoljno zastupljeni u postojećem nastavnom planu i programu (Lučin i Dukić, 2008).

Analizirajući i kontekstualizirajući kronologiju događaja, Bijelić (2008) zaključuje kako javne polemike vezane uz SE u Hrvatskoj ponajprije pokazuju napetost između sekularnog i religijskog diskursa, jasno izražavajući suprotstavljene ideološke pozicije. Sličnu, premda bitno manje intenzivnu, raspravu vezanu uz seksualnost mladih i potrebu za SE izazvao je nedavni UNESCO-v prijedlog. Krajem 2009. godine, UN-ova je organizacija za obrazovanje, znanost i kulturu predstavila kulturno osjetljive Međunarodne smjernice za cjelovitu SE (UNESCO, 2009). Smjernice opisuju šest tematskih cjelina: (1) emocionalno vezivanje, (2) vrijednosti, stavovi i vještine, (3) kultura, društvo i zakon, (4) ljudski razvoj, (5) seksualno ponašanje te (6) seksualno i reproduktivno zdravlje. Predloženi program je razvojni, odnosno prilagođen dobi, pri čemu su teme, pristup i konkretni sadržaji podijeljeni u četiri dobne skupine (5-8, 9-12, 12-15 i 15-18+ godina). UNESCO-ve smjernice predstavljaju prvi pokušaj kulturno osjetljive cjelovite SE.

U ovome radu opisujemo i analiziramo percepciju cjelovite SE u nacionalnom uzorku mladih u dobi između 18 i 25 godina. Cilj rada jest ispitati stavove mladih o potrebi uvođenja SE u hrvatske škole i profilu osoba koje bi trebale izvoditi takav program, kao i stupanj prihvaćanja sadržaja karakterističnih za cjelovitu SE. Uz činjenicu da u nas ne postoje usporedivi podatci (stavovi o SE nisu prikupljani na nacionalno reprezen-

\footnotetext{
${ }^{3}$ U eksperimentalnoj skupini sudjelovalo je 13, a u kontrolnoj skupini 14 osnovnih i srednjih škola.
} 
tativnim uzorcima mladih) te da su dosadašnji istraživački interesi bili više usmjereni na analizu ideoloških sukoba vezanih uz kreiranje i uvođenje programa SE, analizu stavova i želja još donedavno potencijalnih korisnika smatramo iznimno važnom za informiranje budućih obrazovnih politika.

\section{Metode}

\section{Sudionici}

Istraživanje, originalno zamišljeno kao drugi val studije o rizicima HIV-a $\mathrm{u}$ nacionalnoj populaciji mladih, provedeno je metodom ankete u veljači i ožujku 2010. godine na stratificiranom uzorku populacije u dobi između 18 i 25 godina $(\mathrm{N}=1005)$. Kriteriji za stratifikaciju su bili županija, veličina naselja ( $\leq 2000,2001-10.000,10.001-100.000 \mathrm{i}>100.000)$ te dob i spol sudionika. Slučajnim odabirom izabrano je 106 naselja iz svih hrvatskih županija, proporcionalno veličini njihove populacije. Slijedeći detaljno propisanu proceduru nasumičnog odabira kućanstava, ${ }^{4} \mathrm{u}$ svakoj su od tih točaka uzorkovanja anketari intervjuirali, u prosjeku, 10 sudionika. U posljednjem koraku izbora sudionika unutar kućanstava (u slučaju da je više članova bilo odgovarajuće dobi) korištena je metoda posljednjeg rođendana. Razlika između planiranog $\mathrm{i}$ ostvarenog uzorka kretala se $\mathrm{u}$ rasponu od $+/-0,2 \%$, za svaki pojedini kriterij stratificiranja. Uzorkovanje se temeljilo na podacima iz popisa stanovništva (2001.).

\section{Upitnik}

U studiji je korišten upitnik znanja, stavova, ponašanja i vjerovanja. Prvi dio upitnika, za čije je ispunjavanje primijenjena metoda intervjua, sastojao se od indikatora sociodemografskih obilježja, informiranosti o HIV/AIDS-u te stavova o (1) osobama koje žive s HIV/AIDS-om, (2) kondomima i njihovoj upotrebi te (3) seksualnoj edukaciji. Izravno bilježenje odgovora, bez uvida anketara, sudionicima je prepušteno u drugome dijelu upitnika, koji je bio usmjeren na seksualno ponašanje, zadovoljstvo seksualnim životom, seksualne preferencije, odnos prema pornografiji i na ostala relevantna iskustva, uključujući ona vezana uz spolno prenosive bolesti i testiranje na HIV. Ključni su instrumenti pretestirani i potom primijenjeni u prvom nacionalnom istraživanju seksualnosti mladih provedenom 2005. godine (Štulhofer i dr., 2009). Upitnik korišten u ovoj studiji revidirana je verzija upitnika iz tog prvog vala

\footnotetext{
${ }^{4}$ Agencija za istraživanje tržišta koja je provela prikupljanje podataka koristi se ovom standardnom procedurom u svim svojim istraživanjima javnog mnijenja.
} 
studije. Nova je verzija također podvrgnuta pretestiranju, kako bi se provjerila njegova razumljivost i izmjerilo vrijeme potrebno za ispunjavanje. Pretestiranje je izvedeno krajem 2009. godine na uzorku od 103 zagrebačka srednjoškolca i 132 studenta s nekoliko fakulteta Sveučilišta u Zagrebu.

\section{Postupak anketiranja}

Većina anketara uključenih u provođenje terenskog dijela studije bile su žene u dobi između 25 i 35 godina sa značajnim anketarskim iskustvom stečenim u jednoj ili više domaćih istraživačkih agencija. Anketari su prošli dodatni jednodnevni trening, organiziran od strane voditelja studije, posvećen nizu pitanja i problematičnih točaka vezanih uz istraživanja specifičnih, osjetljivih tema na populaciji mladih.

Svi su sudionici intervjuirani u svojim domovima. Stopa odaziva iznosila je $32 \%$, pri čemu je analiza nesudjelovanja uputila na to da je otprilike jedna četvrtina kontaktiranih (24\%) odbila sudjelovati upravo zbog teme istraživanja. Dodatnih $4 \%$ kao razlog je navelo protivljenje roditelja. Nesudjelovanje je bilo znatno izraženije među osobama koje prebivaju u manjim naseljima (manje od 2000 žitelja). Telefonsku kontrolu postupka anketiranja proveli su regionalni koordinatori na 30\% kućanstava uključenih u istraživanje.

Sve predviđene istraživačke postupke odobrilo je Etičko povjerenstvo Filozofskog fakulteta Sveučilišta u Zagrebu (1. 3. 2006.). Prije početka intervjua sudionici su informirani o tijeku, svrsi i nositeljima istraživanja te se od njih tražio usmeni pristanak za sudjelovanje. Po završetku anketiranja, uručena im je brošura s informacijama o HIV/AIDS-u te drugim spolno prenosivim bolestima.

\section{Instrumenti}

Obrazovanje sudionika mjereno je sljedećim pitanjem: »Koju školu ste vi osobno završili?«. Odgovori su bilježeni na skali s četiri stupnja u rasponu od 1 = nezavršena osnovna škola do $4=$ viša škola ili fakultet. $\mathrm{S}$ obzirom na mali broj odgovora u prvoj kategoriji, nezavršena i završena osnovna škola rekodirane su u jednu kategoriju. Obrazovanje oca $i$ majke mjereno je na isti način, pri čemu je zbroj tih dviju varijabli (među kojima je utvrđena značajna povezanost: Kendallov $\tau=0,49$; $\mathrm{p}<$ $0,001)$ korišten kao indikator obrazovanja roditelja. Raspon te kompozitne varijable kretao se od 2 (oba roditelja s osnovnoškolskim obrazovanjem) do 6 (oba roditelja s višim ili visokim obrazovanjem). Indikator veličine prebivališta u kojem je sudionik/ca proveo/la najveći dio života uključi- 
vao je pet kategorija (od $1=$ manje od 10.000 stanovnika do $5=$ više od 500.000 stanovnika). Religioznost - definirana učestalošću sudjelovanja $\mathrm{u}$ religijskim obredima, s iznimkom posebnih prigoda poput vjenčanja, pogreba, krštenja, božićne mise itd. - mjerena je sljedećom skalom: $1=$ nisam vjernik, 2 = nikada ne pohađam obrede, $3=$ jednom $\mathrm{u}$ nekoliko godina, $4=$ nekoliko puta godišnje, $5=$ jednom mjesečno, $6=$ jednom tjedno, 7 = gotovo svakodnevno. Vjera je mjerena validiranim instrumentom (Bezinović, Marinović Bobinac i Marinović Jerolimov, 2005) sastavljenim od pet tvrdnji (»Živim kako moja vjera nalaže«, »Imam osjećaj da me Bog čuva« itd.) kojima je pridružena skala za odgovor s pet stupnjeva (od 1 = uopće se ne odnosi na mene do $5=$ u potpunosti se odnosi na mene). U ovome je istraživanju unutarnja pouzdanost skale iznosila 0,91. Kako bi se izbjegli efekti multikolinearnosti u višestrukoj regresijskoj analizi (korelacija među česticama koje indiciraju religioznost i vjeru je varirala između 0,54 i 0,71 ), rezultati na indikatorima religioznosti i vjere su pretvoreni u $z$-vrijednosti, a potom uvršteni u aditivnu skalu vjere $i$ religioznosti.

Indeks spolne egalitarnosti je aditivna skala sastavljena od četiriju čestica (npr. »Muškarac treba biti taj koji inicira seksualni odnos« ili »Gore je ako žena često mijenja seksualne partnere, nego ako to radi muškarac«) koje su međusobno zadovoljavajuće povezane (Cronbachov $\alpha=0,78$ ). Odgovori su bilježeni na skali slaganja Likertovog tipa s pet stupnjeva (od 1 $=$ uopće se ne slažem do $5=$ u potpunosti se slažem). Nakon što su vrijednosti obratno rekodirane, veći rezultat označava veće prihvaćanje spolne jednakosti.

Seksualna aktivnost definirana je kroz iskustvo seksualnog odnosa. Sudionici koji još nisu imali to iskustvo u ovome su radu označeni kao seksualno neiskusni, što dakako ne znači kako te osobe nemaju seksualni život. Informiranost o HIV/AIDS-u mjerena je s pomoću sedam međunarodno standardiziranih pitanja (tzv. UNGASS indikatori; UNAIDS, 2007.), od kojih su pet vezana uz poznavanje mogućih načina prijenosa virusa (»Može li se HIV prenijeti ubodom komarca?«, »Može li se HIV prenijeti seksualnim odnosom s osobom koja izgleda zdravo?« itd.), a preostala dva uz načine zaštite (»Može li se zaštititi od HIV-a pravilnom uporabom kondoma? « i »Može li se zaštititi od HIV-a imajući seksualne odnose samo s jednom, nezaraženom i vjernom, osobom?«). Odgovori su bilježeni na skali s trima stupnjevima (da, ne, ne znam). Nakon što su odgovori rekodirani kao točni (1) ili netočni (0), formirana je aditivna skala u rasponu od 0 (niti jedan točan odgovor) do 7 (svi odgovori su točni). 
Odnos prema uvođenju SE u hrvatski obrazovni sustav mjeren je sljedećim pitanjem: »Kakvo je Vaše mišljenje o potrebi uvođenja seksualnog odgoja i edukacije u hrvatske škole?«. Kao odgovor su bile ponuđene tri kategorije: »Ne bi ga trebalo uvesti«, »Trebalo bi ga uvesti« i »Ne znam«. Pitanje »Tko bi, prema Vašem mišljenju, trebao voditi seksualni odgoj i edukaciju u školi?« korišteno je za procjenu stava o idealnom profilu osobe koja bi izvodila SE. Sudionici su mogli birati između razrednika/ce, nastavnika/ce biologije, vjeroučitelja/ice, školskog pedagoga/inje ili psihologa/inje, liječnika/ce, mlađe osobe (učeni$\mathrm{ka} / \mathrm{ce}$ ili studenta/ice), educirane za izvođenje takve nastave ili nekog drugoga. ${ }^{5}$

Razmišljanja o sadržajima jednoga mogućeg školskog programa cjelovite seksualne edukacije zahvaćena su sljedećim pitanjem: »Procijenite koliko bi bilo važno svaku od niže ponuđenih tema uključiti u budući program seksualnog odgoja i edukacije za hrvatske škole«. Sudionik/ca je dobio karticu s 11 tema i njihovim glavnim odrednicama (usp. prvi stupac u Tablici 1) te je zamoljen/na da na skali od $1=$ nevažno do $4=$ izrazito važno procijeni svaku pojedinu temu. Svih 11 čestica uvršteno je u aditivnu mjeru (Cronbachov $\alpha=0,84$ ) koja je potom podijeljena $\mathrm{s}$ brojem čestica. ${ }^{6}$ Teorijski raspon tako dobivene kompozitne varijable je $1-4$, pri čemu viši rezultat označava veću važnost ponuđenih tema. Analiza distribucije kompozitne varijable procjene važnosti sadržaja SE ukazala je na blagu negativnu zakošenost (koeficijent asimetrije $=-0,35$ ) te šiljatost (koeficijent zaobljenosti $=-0,16)$.

Kao što je već prethodno spomenuto, operacionalizacija sadržaja programa SE temeljila se na nedavnom UNESCO-vu prijedlogu (multi)kulturno osviještene koncepcije cjelovite SE za četiri dobne skupine u rasponu od 5 do 18 godina (UNESCO, 2009). Kao što je prikazano u Tablici 1, 11 tematskih cjelina uključenih u naš upitnik u velikoj mjeri pokrivaju sadržaj temeljnih šest dimenzija na kojima počiva UNESCO-v prijedlog. U tom smislu, veći rezultat na kompozitnoj skali važnosti 11 sadržaja SE indicira i veću sklonost cjelovitoj SE u hrvatskim školama.

\footnotetext{
${ }^{5}$ Posljednja je kategorija uključivala molbu da se ta osoba (»netko drugi«) specificira.

${ }^{6}$ Kako bi se provjerilo pokrivaju li čestice jednu latentnu dimenziju, na što veličina koeficijenta unutarnje povezanosti upućuje, provedena je i analiza glavnih komponenti. Rezultati su pokazali kako je svih 11 čestica umjereno do visoko zasićeno $(>0,50)$ jednom komponentom koja je protumačila $40 \%$ ukupne varijance. Svojstvena vrijednost komponente iznosila je 4,38.
} 
Tablica 1. Operacionalizacija UNESCO-vih međunarodnih smjernica za seksualnu edukaciju u školi

\begin{tabular}{|c|c|}
\hline Tematske jedinice u upitniku HIV i mladi 2010. & $\begin{array}{l}\text { UNESCO-ve smjernice } \\
\text { (dimenzije 1-6)* }\end{array}$ \\
\hline $\begin{array}{l}\text { 1. Seksualnost kao pozitivna vrijednost } \\
\text { (Važnost seksualnosti u ljudskom životu, seksualni } \\
\text { užitak, seksualnost i komunikacija...) }\end{array}$ & 2,5 \\
\hline $\begin{array}{l}\text { 2. Spolno prenosive bolesti i zaštita } \\
\text { (Načini prijenosa, simptomi i liječenje, pravilna } \\
\text { uporaba zaštite, djelotvornost kondoma, odgađanje } \\
\text { seksualne aktivnosti...) }\end{array}$ & 6 \\
\hline $\begin{array}{l}\text { 3. Društvo, mediji i seksualnost } \\
\text { (Prikaz spolnosti u medijima, utjecaj popularnih } \\
\text { medija na seksualnost mladih, utjecaj pornografije...) }\end{array}$ & 2,3 \\
\hline $\begin{array}{l}\text { 4. Seksualno uznemiravanje i zlostavljanje u } \\
\text { adolescentskim vezama } \\
\text { (Kako ih prepoznati, njihova učestalost, gdje } \\
\text { potražiti pomoć...) }\end{array}$ & 2,3 \\
\hline $\begin{array}{l}\text { 5. Spolna anatomija i ljudsko seksualno funkcioniranje } \\
\text { (Ženski i muški spolni organ i seksualna fiziologija, } \\
\text { uloga hormona u spolnosti...) }\end{array}$ & 4 \\
\hline $\begin{array}{l}\text { 6. Seksualna aktivnost } \\
\text { (Seksualna zrelost, seksualni odnos, seksualni rizici } \\
\text { i odgovorno ponašanje, masturbacija, odgađanje } \\
\text { početka seksualne aktivnosti...) }\end{array}$ & $2,4,5$ \\
\hline $\begin{array}{l}\text { 7. Emocionalno vezivanje, partnerstvo i brak } \\
\text { (Ljubav, ostvarivanje i održavanje intimnosti i } \\
\text { međusobnog povjerenja...) }\end{array}$ & 1 \\
\hline $\begin{array}{l}\text { 8. Trudnoća i roditeljstvo } \\
\text { (Planiranje obitelji, trudnoća, testovi za trudnoću, } \\
\text { prekid trudnoće, roditeljstvo, umjetna oplodnja...) }\end{array}$ & 1,6 \\
\hline $\begin{array}{l}\text { 9. Spolna i rodna ravnopravnost } \\
\text { (Razlikovanje pojmova spol i rod, patrijarhalna } \\
\text { kultura, feminizam i borba za jednaka prava...) }\end{array}$ & 3 \\
\hline $\begin{array}{l}\text { 10. Seksualne različitosti } \\
\text { (Seksualna orijentacija, homoseksualnost, } \\
\text { transseksualnost, diskriminacija, prava istospolnih } \\
\text { parova...) }\end{array}$ & 1 \\
\hline $\begin{array}{l}\text { 11. Religija i seksualnost } \\
\text { (Odnos različitih religija prema seksualnosti, } \\
\text { moralnost i seksualnost, katolički pogled na } \\
\text { seksualnost...) }\end{array}$ & 3 \\
\hline
\end{tabular}

* Temeljne dimenzije UNESCO-vih Smjernica za seksualnu edukaciju: (1) emocionalne veze i vezivanje, (2) vrijednosti, stavovi i vještine, (3) kultura, društvo i zakonske norme, (4) ljudski razvoj, (5) seksualno ponašanje i (6) seksualno i reproduktivno zdravlje. 


\section{Rezultati}

\section{Slaganje $s$ uvođenjem SE}

Na pitanje bi li u hrvatske škole trebalo uvesti »seksualni odgoj i edukaciju«, velika je većina sudionika $(83,8 \%)$ odgovorila potvrdno. Suprotno je mišljenje bilo zastupljenije među osobama koje još nisu imale seksualni odnos $\left(\chi^{2}=17,2 ; p<0,001\right)$ i muškarcima $\left(\chi^{2}=19,1 ; p<0,001\right)$. U oba slučaja, veličina je efekta, odnosno utjecaja obilježja na stav o uvođenju $\mathrm{SE}$, bila mala (Cramerov $\mathrm{V}=0,13$ i 0,14 ). Religioznost nije bila povezana sa stavom o potrebi uvođenja SE.

U usporedbi s prvim valom studije, provedenim 2005. godine na usporedivom nacionalnom uzorku mladih (Štulhofer i dr., 2006), opažena je mala ali statistički značajna razlika u slaganju s uvođenjem SE u hrvatskim školama. Za razliku od 2005. godine, kad je $86 \%$ sudionika pozitivno odgovorilo na pitanje o potrebi uvođenja SE, pet godina kasnije proporcija se smanjila na $84 \%$. Premda je u oba spola zabilježena statistički značajna razlika između dva mjerenja $\left(\chi_{\text {žene }}^{2}=4,80, \mathrm{p}<0,05 ; \chi_{\text {muškarci }}^{2}=32,07, \mathrm{p}<\right.$ 0,001 , veličina razlika sugerira da je utjecaj praktički zanemariv.

\section{Idealni profesionalni profil nastavnika/ce SE}

Upitani za profesionalni profil osobe koja bi, po njihovu mišljenju, trebala izvoditi program SE u školi, sudionici su najčešće odabirali liječnika/cu $(36,9 \%)$, a potom mlađu osobu koja bi bila posebno educirana za izvođenje takvog programa (23\%). Na trećem je mjestu naveden školski pedagog/ inja ili psiholog/inja (17\%). Imajući na umu da je nedavna, kasnije napuštena, inicijativa Ministarstva znanosti, obrazovanja i športa predviđala da će program Zdravstvenog odgoja (unutar kojeg su se trebale izvoditi i nastavne jedinice vezane uz seksualnost) izvoditi razrednici (MZOŠ, 2005), zanimljivo je da je samo 3,5\% sudionika navelo razrednika/cu kao osobu kojoj bi trebalo povjeriti taj posao. Od 901 osobe koje su odgovorile na to pitanje, samo su tri muškarca i jedna žena smatrali da bi vjeroučitelj/ica bio/la najbolji izbor za voditelja/icu programa SE.

\section{Procjena važnosti sadržaja cjelovite SE}

Kao što pokazuju rezultati prikazani u Tablici 2, svih 11 tema dobilo je prosječnu ocjenu veću od 1,5 , što znači da niti jedna tema nije procijenjena kao nevažna. Modalna vrijednost za cijelu skalu iznosi 3 (prosječna vrijednost $=$ 3,26; SD = 0,46), što pokazuje većinsku sklonost koncepciji cjelovite SE. Tri najbolje ocijenjene teme, »Spolno prenosive bolesti i načini zaštite«, »Trudnoća i roditeljstvo« te »Seksualno uznemiravanje i zlostavljanje u adolescentskim vezama«, ujedno su i jedine koje su sudionici ocijenili iznimno važnima 
(prosječna ocjena $\geq 3,5$ ). Najmanje važnom ocijenjena je tema »Religija $\mathrm{i}$ seksualnost«. Protivno očekivanju, analize nisu ukazale na spolnu specifičnost rangiranja tri najprihvaćenije, odnosno najmanje prihvaćene tematske jedinice. Kad je riječ o procjeni važnosti pojedinih tema, statistički značajne spolne razlike evidentirane su na tematskim cjelinama »Seksualno uznemiravanje i zlostavljanje«, »Spolna anatomija i seksualna funkcija« te »Spolna i rodna ravnopravnost«. U svim trima slučajevima, žene su pokazale veće prihvaćanje, to jest tematsku su cjelinu označile važnijom, od muškaraca.

Tablica 2. Prosječna procjena važnosti i rangiranje sadržaja seksualne edukacije

\begin{tabular}{|c|c|c|c|c|c|}
\hline Tematske jedinice & $\begin{array}{l}\text { Prosječna } \\
\text { vrijednost }\end{array}$ & $S D$ & Rang & $\begin{array}{l}M / \check{Z}^{a} \\
(d)^{c}\end{array}$ & $\begin{array}{l}N R / R^{b} \\
(d)^{c}\end{array}$ \\
\hline $\begin{array}{l}\text { Seksualnost kao pozitivna } \\
\text { vrijednost }\end{array}$ & 3,04 & 0,72 & 9 & $8 / 9$ & $\begin{array}{l}8 / 11^{*} \\
(0,37)\end{array}$ \\
\hline Spolno prenosive bolesti i zaštita & 3,68 & 0,54 & 1 & $1 / 1$ & $1 / 1$ \\
\hline Društvo, mediji i seksualnost & 3,01 & 0,80 & 10 & $9 / 10$ & $10 / 10$ \\
\hline $\begin{array}{l}\text { Seksualno uznemiravanje i } \\
\text { zlostavljanje u adolescentskim } \\
\text { vezama }\end{array}$ & 3,53 & 0,61 & 3 & $\begin{array}{c}3 / 3^{*} \\
(-0,30)\end{array}$ & $3 / 4$ \\
\hline $\begin{array}{l}\text { Spolna anatomija i ljudsko } \\
\text { seksualno funkcioniranje }\end{array}$ & 3,29 & 0,71 & 6 & $\begin{array}{c}6 / 6^{*} \\
(-0,24)\end{array}$ & $6 / 6$ \\
\hline Seksualna aktivnost & 3,36 & 0,70 & 5 & $\begin{array}{c}5 / 5 \\
(-0,14)\end{array}$ & $4 / 5$ \\
\hline $\begin{array}{l}\text { Emocionalno vezivanje, } \\
\text { partnerstvo i brak }\end{array}$ & 3,40 & 0,69 & 4 & $4 / 4$ & $\begin{array}{c}5 / 3^{*} \\
(-0,28)\end{array}$ \\
\hline Trudnoća i roditeljstvo & 3,58 & 0,58 & 2 & $2 / 2$ & $2 / 2$ \\
\hline Spolna i rodna ravnopravnost & 3,24 & 0,77 & 7 & $\begin{array}{c}7 / 7 * \\
(-0,22)\end{array}$ & $7 / 7$ \\
\hline Seksualne različitosti & 3,07 & 0,85 & 8 & $\begin{array}{c}10 / 8 * \\
(-0,28)\end{array}$ & $9 / 9$ \\
\hline Religija i seksualnost & 2,66 & 1,00 & 11 & $11 / 11$ & $\begin{array}{l}11 / 8^{*} \\
(0,96)\end{array}$ \\
\hline
\end{tabular}

${ }^{a}$ Lijeva brojka prikazuje rang tematske jedinice u muškom $(n=510)$, a desna brojka $\mathrm{u}$ ženskom poduzorku $(\mathrm{n}=495)$

${ }^{\mathrm{b}}$ Lijeva brojka prikazuje rang tematske jednice u poduzorku sudionika koji ne pohađaju vjerske obrede ili to čine vrlo rijetko $(\mathrm{n}=336)$, a desna brojka označava rang u poduzorku izrazito religioznih sudionika $(\mathrm{n}=139)$

${ }^{\mathrm{c}}$ Cohenov $d$ indeks veličine efekta; vrijednosti su prikazane samo za čestice koje obilježava statistički značajna razlika među skupinama (testirana $t$-testom)

* Značajnost razlike među skupinama na razini $\mathrm{p}<0,0045$, određena prema Bonferronijevoj korekciji za višestruke usporedbe (Bonferroni $\alpha=0,0045$ ) 
Za svaku od ponuđenih tema, u sljedećem smo koraku usporedili prosječne vrijednosti sudionika koji su iskazali najmanju razinu religioznosti (uopće ne pohađaju vjerske obrede ili to čine jednom u nekoliko godina; $\mathrm{n}=336$ ) te onih koji su iskazali najveću razinu religioznosti (pohađaju vjerske obrede jednom tjedno ili češće; $n=139$ ). Takva je analiza polarnih ekstrema (Hair i dr., 1998: 257) ukazala na samo tri statistički značajne razlike. (Razina statističke vjerojatnosti, kao i u slučaju testiranja razlika prema spolu, određena je prema Bonferronijevoj korekciji za višestruke usporedbe.) Predvidljivo, religiozni sudionici su pokazali veći interes za teme »Religija i seksualnost« te »Emocionalno vezivanje, partnerstvo i brak«. Najmanje religiozni sudionici su pak označili prvu od jedanaest ponuđenih tema, »Seksualnost kao pozitivna vrijednost«, značajno važnijom od izrazito religioznih vršnjaka. No, veličina razlike, mjerena Cohenovim $d$ koeficijentom, jedino se u slučaju teme »Religija i seksualnost« može označiti snažnom (Cohen, 1988).

Ukupno gledajući, najmanje i najviše religiozni sudionici vrlo se malo razlikuju u rangiranju važnosti tema. Prva se dva ranga ne razlikuju među skupinama, kao ni dva pretposljednja. Najmanje religiozni sudionici trećom po važnosti smatraju temu »Seksualno uznemiravanje i zlostavljanje«, dok je za najreligioznije to tema »Emocionalno vezivanje, partnerstvo i brak«. Potonju tematsku jedinicu »Religija i seksualnost« smještaju na osmo od jedanaaest mjesta rang liste, dok je za najmanje religiozne mlade ljude ta tema posljednja po važnosti.

Kako bismo analizirali povezanost temeljnih sociodemografskih i socioseksualnih dimenzija s jedne te procjene važnosti predloženih tema SE s druge strane, proveli smo niz bivarijatnih testova (Tablica 3). Čimbenicima koji značajno povećavaju prihvaćanje cjelovite SE pokazali su se dob (p $<0,01)$, ženski spol $(\mathrm{p}<0,001)$, obrazovanje $(\mathrm{p}<0,01)$ te religioznost $(\mathrm{p}$ $<0,05)$. U sljedećem smo koraku proveli višestruku regresijsku analizu, u koju su uz sociodemografske varijable uvršteni i indikator spolne egalitarnosti te informiranost o HIV/AIDS-u (Tablica 4). Indikator spolne egalitarnosti uveden je radi kontrole utjecaja tradicionalnih stavova prema spolnim ulogama, kako bismo pod religioznošću poglavito odmjerili efekt vjerskog morala, dok je posljednji indikator uvršten kako bi se ispitalo povećava li informiranost o HIV/AIDS-u pozitivnu procjenu cjelovite SE. ${ }^{7}$ Premda je postotak protumačene varijance kriterija zanemariv $\left(\mathrm{R}^{2}=0,07\right)$, model se pokazao značajnim $(F=7,68 ; p<0,001)$. Kao značajni sociodemografski

\footnotetext{
${ }^{7}$ U hrvatskim je školama HIV/AIDS, vrlo vjerojatno, trenutačno najzastupljenija tema vezana uz ljudsku spolnost; 94,5\% sudionika u našem istraživanju izjavilo je kako je tijekom školovanja dobilo informacije o HIV/AIDS-u.
} 
prediktori važnosti cjelovite SE potvrđeni su dob, spol te indikator vjere i religioznosti. U svim trima slučajevima, povezanosti su vrlo slabe, odnosno od male praktične važnosti. Informiranost o HIV/AIDS-u i spolni neegalitarizam su se također pokazali značajnim korelatima. Prema rezultatima, veća informiranost i spolna egalitarnost odgovarali su većoj procijenjenoj važnosti cjelovite SE.

Tablica 3. Razlike u prihvaćanju sustavne seksualne edukacije s obzirom na sociodemografska i socioseksualna obilježja sudionika

\begin{tabular}{|c|c|c|c|c|}
\hline & $\begin{array}{l}\text { Prosječni } \\
\text { rezultat* }^{*}\end{array}$ & $S D$ & $F$ & $p<$ \\
\hline Dob & & & 1,87 & 0,01 \\
\hline $18-21$ & 3,21 & 0,45 & & \\
\hline $22-25$ & 3,31 & 0,45 & & \\
\hline Spol & & & 16,58 & 0,001 \\
\hline žene & 3,32 & 0,42 & & \\
\hline muškarci & 3,20 & 0,48 & & \\
\hline Obrazovanje & & & 4,77 & 0,01 \\
\hline osnovna škola & 3,16 & 0,42 & & \\
\hline srednja škola & 3,27 & 0,47 & & \\
\hline viša ili visoka škola & 3,36 & 0,41 & & \\
\hline Veličina prebivališta & & & 2,62 & n.z. \\
\hline do 10.000 stanovnika & 3,28 & 0,46 & & \\
\hline 10.000-100.000 stanovnika & 3,28 & 0,44 & & \\
\hline 100.000 stanovnika ili više & 3,20 & 0,47 & & \\
\hline Sudjelovanje $u$ vjerskim obredima & & & 4,27 & 0,01 \\
\hline nikada ili rijetko & 3,27 & 0,48 & & \\
\hline povremeno & 3,23 & 0,46 & & \\
\hline redovito (jednom tjedno ili češće) & 3,36 & 0,40 & & \\
\hline Seksualna aktivnost & & & 1,68 & n.z. \\
\hline ne & 3,31 & 0,45 & & \\
\hline da & 3,26 & 0,46 & & \\
\hline
\end{tabular}

* Raspon kompozitnog indikatora iznosi 1-5

Nalaz o povezanosti religioznosti i procijenjene važnosti cjelovite SE je neočekivan. Ne bi li trebalo očekivati da će religiozniji sudionici biti manje skloni takvoj koncepciji od ostalih? Imajući na umu nalaz o velikoj razlici u prihvaćanju jedne od 11 tema (»Religioznost i seksualnost«) između najreligioznijih i najmanje religioznih sudionika, regresijski je model prikazan u Tablici 4 ponovljen s revidiranom zavisnom varijablom iz koje je izbačena čestica »Religioznost i seksualnost« (analiza nije prikazana u 
tablicama). Opisana je promjena rezultirala nestankom statističke značajnosti vjere i religioznosti $(\mathrm{t}=-0,12, \mathrm{df}=291, \mathrm{p}>0,90)$ kao prediktora procjene preostalih 10 tema SE. ${ }^{8}$

Tablica 4. Sociodemografski i socioseksualni korelati prihvaćanja sustavne seksualne edukacije $(\mathrm{N}=867)^{*}$

\begin{tabular}{lccc}
\hline & $\begin{array}{c}\text { Standardna } \\
\text { pogreška } \\
\text { procjene }\end{array}$ & $\begin{array}{c}\text { Standardizirani } \\
\text { koeficijent } \\
\text { regresije }(\beta)\end{array}$ & $p<$ \\
\hline Dob & 0,01 & 0,12 & 0,01 \\
Spol $(1$ = ženski) & 0,03 & 0,09 & 0,05 \\
Obrazovanje & 0,04 & 0,03 & n.z. \\
Obrazovanje roditelja & 0,02 & $-0,01$ & n.z. \\
Veličina mjesta najdužeg prebivališta & 0,02 & $-0,05$ & n.z. \\
Vjera i religioznost & 0,01 & 0,12 & 0,001 \\
Spolna egalitarnost & 0,00 & 0,12 & 0,001 \\
Informiranost o HIV/AIDS-u & 0,03 & 0,11 & 0,001 \\
Seksualna aktivnost $(1=d a)$ & 0,05 & $-0,04$ & n. z. \\
\hline
\end{tabular}

* Kad se iz kriterijske varijable ukloni tematska jedinica »Religija i seksualnost«, prediktor vjera i religioznost prestaje biti statistički značajan (pri čemu značajnost ostalih nezavisnih varijabli ostaje nepromijenjena)

\section{Diskusija}

U ovome smo radu analizirali stavove mladih prema uvođenju SE u hrvatske škole i profilu osoba koje bi je trebale izvoditi, kao i procjenu važnosti sadržaja koji uobičajeno čine tzv. cjelovitu SE. Dobiveni rezultati upućuju na rašireno prihvaćanje potrebe za SE u hrvatskim školama. Velika većina sudionika u nacionalnom uzorku drži da bi takav program trebao biti sastavni dio formalnog obrazovanja. Istraživanja provedena u drugim zemljama dolaze do sličnih nalaza (usp. Forrest i dr., 2004; Kakavoulis i Forrest, 1999). Primjerice, Donati i dr. (2000) proveli su istraživanje na uzorku mladih Talijana u dobi 14-21 godina koje je pokazalo kako ih čak $96 \%$ podržava školske programe SE. Kad je riječ o roditeljima, postotci prihvaćanja nešto su manji, ali je dominantni stav podjednako pozitivan (Eisenberg i dr, 2008; Kirana i dr, 2007). Tako je u nedavnom američkom istraživanju, provedenom u saveznoj državi koja provodi apstinencijsku SE, ideju cjelovite SE u školama podržalo $89 \%$ roditelja (Ito i dr., 2006). Slične

\footnotetext{
${ }^{8}$ Prema očekivanju, isti je rezultat dobiven i na bivarijatnoj razini.
} 
proporcije navode i drugi autori, primjerice Eisenberg i dr. (2008; 89,3\%) te Constantine, Jerman i Huang (2007; 82\%).

Procjena jedanaest tematskih cjelina, oslonjenih na nedavno objavljene UNESCO-ve smjernice (UNESCO, 2009), kojima smo nastojali obuhvatiti sve relevantne sadržaje programa cjelovite SE pokazala se značajno povezana s dobi, spolom te religioznošću. Sva su tri prediktora bila pozitivno povezana $\mathrm{s}$ procijenjenom važnosti tema cjelovite SE, pri čemu je značajnost efekta religioznosti počivala isključivo na procjeni jedne specifične teme. Treba naglasiti da su većinu sadržaja sudionici prosječno okarakterizirali kao prilično važne za budući program seksualne edukacije, pri čemu su kao najvažnije označene praktične teme vezane uz seksualno i reproduktivno zdravlje (»Spolno prenosive bolesti i načini zaštite« te »Trudnoća i roditeljstvo«).

Prema očekivanju, najveća je razlika u procjeni važnosti sadržaja SE između najreligioznijih i najmanje religioznih sudionika zabilježena na temi »Religija i seksualnost«. Statistički značajne spolne razlike su evidentirane na četirima od jedanaest tema, pri čemu je veličina razlika u svim četirima slučajevima razmjerno mala. U usporedbi s muškarcima, žene su označile važnijim teme koje raspravljaju diskriminaciju žena ili nasilje prema ženama, odnosno one koje razrađuju spolnu i reproduktivnu anatomiju, fiziologiju i funkciju te seksualne različitosti.

Uz demografske čimbenike, multivarijatna je analiza prediktora procjene cjelovite SE ukazala i na važnost informiranosti o HIV/AIDS-u te prihvaćanja spolne jednakosti. Povezanost informiranosti o HIV-u i veće procjene važnosti cjelovite SE moguće je interpretirati na više načina. Moguće je da informacije o jednom aspektu ljudske seksualnosti dovode do povećanog interesa za razumijevanje ostalih dimenzija tog složenog fenomena. S druge strane, moguće je da mladi žele više informacija o rizičnim ponašanjima i načinima zaštite, odnosno da ih razmjerno fragmentarno informiranje čini svjesnijima vlastitog neznanja i time sklonijima SE. Veza između spolno egalitarnih stavova i procjene važnosti SE mogla bi biti dijelom direktna (SE podučava o seksualnosti drugoga spola i međusobnom razumijevanju), a dijelom posredovana netradicionalnim vrijednostima iz kojih proizlazi i koncepcija spolne ravnopravnosti te ideja o otvorenom informiranju mladih o njihovoj spolnosti. Imajući na umu da je provedena regresijska analiza objasnila manje od desetog dijela varijance procjene važnosti sadržaja SE, navedene povezanosti, premda statistički značajne, imaju malu praktičnu važnost.

Kad je riječ o profesionalnom profilu osobe koja bi trebala izvoditi budući program SE, rezultati istraživanja pokazali su razmimoilaženje mi- 
šljenja mladih ljudi i koncepcije Ministarstva znanosti, obrazovanja i športa, izražene u nedavno napuštenoj inicijativi za uvođenje SE u hrvatske škole. Dok su sudionici najčešće isticali liječnika/icu, a potom posebno educiranu mladu osobu (vršnjaci-edukatori), Ministarstvo je bilo inzistiralo na nastavnicima. Takve razlike između obrazovne politike i želja korisnika nisu, dakako, nepoznate i u drugim zemljama (Forrest i dr., 2004), pri čemu inozemna iskustva upućuju na potrebu za suradnjom između škole, učenika, njihovih roditelja i društvene zajednice u izradi i implementaciji SE (Eisenberg i dr., 2008; Kirana i dr., 2007).

\section{Ograničenja studije}

Potrebno je prokomentirati i nekoliko ograničenja naše studije. Prvo je vezano uz razmjerno slab odaziv mladih za sudjelovanje u istraživanju. Premda zabilježeni postotak sudjelovanja ne odstupa od danas, čini se, uobičajenih stopa odaziva u domaćim istraživanjima javnog mnijenja, ${ }^{9}$ poznato je da $\mathrm{u}$ istraživanjima koja se bave seksualnošću poglavito sudjeluju osobe permisivnijih stavova, koje otvorenije komuniciraju o seksualnosti (Wiederman, 1999). Imajući na umu da je otprilike jedna četvrtina kontaktiranih mladih osoba odbila sudjelovati u istraživanju zbog teme (rizici HIV-a) najvjerojatnije ne želeći odgovarati na pitanja o vlastitoj seksualnosti ili se bojeći reakcije roditelja - sklonost je SE vjerojatno precijenjena u ovom istraživanju. ${ }^{10}$ Opisana je pristranost uzorka vrlo vjerojatno utjecala i na procjenu važnosti pojedinih tema SE.

Drugo moguće ograničenje odnosi se na dob sudionika. Činjenica je da u istraživanju nisu sudjelovali učenici osnovnih škola te da je udio srednjoškolaca bio vrlo malen. U tom smislu, većina naših sudionika nisu potencijalni korisnici seksualne edukacije u školi, nego mladi ljudi koji su završili sekundarno školovanje prije 1-7 godina. Njihovo je mišljenje o uvođenju i sadržajima seksualne edukacije danas vjerojatno drukčije no što je bilo u vrijeme kad su pohađali srednju školu. Ugrožava li to valjanost naših procjena? Ne nužno, s obzirom na to da bi procjena važnosti sadržaja seksualne edukacije mogla počivati i na životnom iskustvu te neopterećenosti pitanjem hoće li uvođenje novoga školskog sadržaja povećati osobne obveze. U tom smislu, nešto stariji sudionici mogli bi imati bolji uvid u važnost SE od mladih koji još uvijek pohađaju školu, na što upućuje i sta-

\footnotetext{
${ }^{9}$ Prema informacijama koje je treći autor rada dobio u razgovoru s dugogodišnjim djelatnikom agencije Puls (11. 2. 2011.).

${ }^{10}$ Osim razloga za odbijanje, $\mathrm{u}$ istraživanju nisu prikupljane druge informacije o osobama koje nisu prihvatile poziv za sudjelovanje u istraživanju.
} 
tistički značajna povezanost između dobi i procjene važnosti cjelovite SE zabilježena u ovoj studiji (usp. Tablicu 4).

Moglo bi se prigovoriti da naša operacionalizacija UNESCO-vih Međunarodnih smjernica omogućuje raznorodna »čitanja«, odnosno da se naših 11 tema mogu različito interpretirati. Takva teza dovodi u pitanje nalaz prema kojem su religiozni i nereligiozni sudionici podjednako zainteresirani za cjelovitu seksualnu edukaciju. Preciznije rečeno, utjecaj se religioznosti na prihvaćanje seksualne edukacije nije pokazao statistički značajnim (nakon što je iz analize isključena 11. tema) jer su religiozni i nereligiozni sudionici posve različito interpretirali sadržaje koje su, potom, procijenili podjednako važnim. Takvo moguće tumačenje dobivenih podataka, prema našem mišljenju, nije osobito uvjerljivo, ali se prigovor ne može u potpunosti odbaciti. Dva su argumenta na kojima temeljimo svoj sud. Prvo, religiozni i nereligiozni sudionici razlikuju se prema stupnju prihvaćanja tri od jedanaest tema, što se protivi tezi da su ponuđeni sadržaji nediskriminativni. Prema nalazima, religiozni sudionici su pokazali snažnije prihvaćanje tema »Emocionalno vezivanje« te »Religija i seksualnost«, odnosno manju sklonost temi »Seksualnost kao pozitivna vrijednost«, od nereligioznih vršnjaka. Uzmemo li u obzir razlike religijskih i sekularnih normi vezanih uz seksualnost mladih, razlike su očekivane - osobito u slučaju prvih dviju tema.

Drugi je argument, pomalo paradoksalno, vezan uz nepostojanje razlika na nizu tema gdje bismo ih očekivali. Na osam od jedanaest tema nisu zabilježene statistički značajne razlike u stupnju prihvaćanja religioznih i nereligioznih sudionika, bez obzira na to što su uključivale sadržaje kao što su informacije o djelotvornosti kondoma, masturbaciji, prekidu trudnoće (abortus), patrijarhalnoj kulturi i feminizmu, diskriminaciji seksualnih manjina te pravima istospolnih parova. Nepostojanje razlika u prihvaćanju tema koje uključuju fenomene o kojima u religijskom diskursu postoji izrazito negativan stav (npr. masturbacija ili uporaba kondoma) sugerira da većina mladih ljudi, bez obzira na stupanj religioznosti, smatra sve navedene sadržaje važnima - ili, preciznije, ne otpisuje ih kao nevažne - za buduću SE. (Takav zaključak podupire i nalaz da je samo četvero sudionika navelo vjeroučitelja/icu kao osobu idealnu za izvođenje SE.) Dakako, to ne briše, niti umanjuje, razlike u sustavu vrijednosti religioznih i nereligioznih mladih ljudi, iz kojih oni procjenjuju važnost određenog sadržaja (primjerice, abortusa) za vlastito ponašanje. U cjelini, dakle, držimo malo vjerojatnom tezu da su sudionici različito interpretirali sadržaj pojedinih tema cjelovite SE.

Zaključno, provedena studija ukazuje na većinsku potporu uvođenju SE u hrvatske škole. Po svemu sudeći, program cjelovite SE - nalik onom 
nedavno predloženom od strane UNESCO-a (UNESCO, 2009) - mogao bi biti prihvatljiv većini mladih ljudi u dobi između 18 i 25 godina, bez obzira na spol i stupanj religioznosti. Ne zanemarujući ozbiljnost opisanih ograničenja studije - među kojima se osobito ističe moguća pristranost nalaza izazvana skromnim odazivom - oba nalaza smatramo važnim uvidom za buduću obrazovnu politiku vezanu uz seksualnost mladih te zaštitu njihova seksualnog i reproduktivnog zdravlja.

\section{LITERATURA}

Bezinović, Petar, Marinović Bobinac, Ankica i Marinović Jerolimov, Dinka (2005). »Kratka ljestvica religioznosti: validacija na uzorku adolescenata«, Društvena istraživanja, 14 (1-2): 135-153.

Bijelić, Nataša (2008). »Sex Education in Croatia: Tensions between Secular and Religious Discourses«, European Journal of Womens Studies, 15 (4): 329-343. doi:10.1177/1350506808095273

Bleakley, Amy, Hennessy, Michael i Fishbein, Martin (2010). »Predicting Preferences for Types of Sex Education in US Schools«, Sexuality Research and Social Policy, 7 (1): 50-57. doi:10.1007/s13178-010-0008-Z

Cohen, Jacob (1988). Statistical Power Analysis for the Behavioral Sciences. 2nd ed. Hillsdale, NJ: Erlbaum.

Constantine, Norman A., Jerman, Petra i Huang, Alice X. (2007). „California Parents' Preferences and Beliefs Regarding School-Based Sex Education Policy«, Perspectives on Sexual and Reproductive Health, 39 (3): 167-175. doi:10.1363/3916707

Cotić, Alozije, Novak-Reiss, Aleksandra, Košiček, Marijan, Tajsl, Štefica i Zadrović, Ante (1973). Spolni odgoj. Zagreb: Školska knjiga.

Council of Representatives (2005). Resolution in Favour of Empirically Supported Sex Education and HIV Prevention Programs for Adolescents.

Donati, Serena, Medda, Emanuela, Spinelli, Angela i Grandolfo, Michele (2000). »Sex Education in Secondary Schools: An Italian Experience«, Journal of Adolescent Health, 26 (4): 303-308. doi:10.1016/S1054-139X(99)00081-6

Donovan, Patricia (1998). »School-Based Sexuality Education: The Issues and Chalenges«, Family Planning Perspectives, 30 (4): 188-193. doi:10.2307/2991682

Eisenberg, Marla, Bernat, Debra, Bearinger, Linda i Resnick, Michael (2008). »Support for Comprehensive Sexuality Education: Perspectives from Parents of School-Age Youth«, Journal of Adolescence Health, 42 (2): 352-359. doi:10.1016/j.jadohealth.2007.09.019

Flaherty-Zonis, Carol (2001). Uvod u ljudsku spolnost. Zagreb: Forum za slobodu odgoja.

Forrest, Simon, Strange, Vicki, Oakley, Ann i RIPPLE Study Team (2004). »What do Young People Want From Sex Education? The Results of a Needs Assesment from a Peer-Led Eduaction Programme«, Culture, Sex and Sexuality, 6 (4): 337-354. doi:10.1080/13691050310001645050 
Grunseit, Anne i Kippax, Susan (1997). »Sexuality Education and Young People’s Sexual Behavior: A Review of Studies«, Journal of Adolescent Research, 12 (4): 421-453. doi:10.1177/0743554897124002

Hair, Joseph E., Anderson, Rolph E., Tatham, Ronald L. i Black, William C. (1998). Multivariate Data Analysis. Upper Saddle River, NJ: Prentice Hall.

Hiršl-Hećej, Vlasta, Dobravc Poljak, Jasmina, Šikanić-Dugić, Nives, Domljan, Mislav Luka i Pustišek, Nives (2006). MEMOAIDS II: program edukacije vršnjaka u prevenciji HIV/AIDS-a za adolescente. Zagreb: Klinika za dječje bolesti.

Hodžić, Amir i Štulhofer, Aleksandar (2002). »Seksualna edukacija u školi: inozemna iskustva«, Napredak, 143 (4): 452-461.

Irvine, Janice (2000). »Doing it with words: Discourse and the sex education culture wars«, Critical Inquiry, 27 (4): 58-76. doi:10.1086/448998

Ito, Kristin E., Gizlice, Ziya, Owen-O’Dowd, Judy, Foust, Evelyn, Leonne, Peter A. i Miller, William C. (2006). »Parent opinion of sexuality education in a state with mandiated abstinence education: Does policy match parental preference?«, Journal of Adolescent Health, 39 (5): 634-641. doi:10.1016/j.jadohealth.2006.04.022

Izvještaj o provedbi projekta vanjskog vrjednovanja »Eksperimentalni program zdravstvenog odgoja i obrazovanja u osnovnim i srednjim školama 2008. godine [2008]. Zagreb: Nacionalni centar za vanjsko vrednovanje obrazovanja.

Kakavoulis, Alexandros i Forrest, Joan (1999). „Attitudes and Values in Sexual Behaviour and Sex Education: A Cross-Cultural Study Among University Students in Greece and Scotland«, International Review of Education, 45 (2): 137-150.

Kirana, Paraskevi-Sofia, Nakopoulou, Evangelia, Akrita, Ioanna i Papaharitou, Stamatis (2007). "Attitudes of Parents and Health Promoters in Greece Concerning Sex Education of Adolescents«, Sex Education, 7 (3): 265-276. doi:10.1080/14681810701448085

Kirby, Douglas (1999). »Reflections on Two Decades of Research on Teen Sexual Behavior and Pregnancy«, Journal of School Health, 69 (3): 89-95. doi:10.1111/j.1746-1561.1999.tb07214.x

Kirby, Douglas B., Laris, B. A. i Rolleri, Lori A. (2007). »Sex and HIV Education Programs: Their Impact on Sexual Behaviors of Young People Throughout the World«, Journal of Adolescent Health, 40 (3): 206-217. doi:10.1016/j.jadohealth.2006.11.143

Klein, Marty (2006). America's War on Sex: The Attack on Law, Lust, and Liberty. Westport, CT: Preager.

Kohler, Pamela K., Manhart, Lisa E. i Lafferty, William E. (2008). »AbstinenceOnly and Comprehensive Sex Education and the Initiation of Sexual Activity and Teen Pregnancy«, Journal of Adolescent Health, 42 (4): 344-351. doi:10.1016/j.jadohealth.2007.08.026

Lučin, Ana i Dukić, Snježana (2008). »Država odustala od seksualnog odgoja«, Slobodna Dalmacija, http://www.slobodnadalmacija.hr/Hrvatska/tabid/66/articleType/ArticleView/articleId/\%2034909/Default.aspx (01. 07. 2010.).

Maleš, Dubravka (2000). »Spolni odgoj u kontekstu prava djeteta«, Dijete $i$ društvo, 2 (2): 201-215. 
MZOŠ (2005). Natječaj za prijavu prijedloga eksperimentalnih programa zdravstvenog odgoja i obrazovanja u osnovnim i srednjim školama (Zagreb: Ministarstvo znanosti, obrazovanja i športa), http://public.mzos.hr/fgs.axd?id=14681 (20. 07. 2010.).

Pavlović, Kristina (2004). »Program cjelovitog spolnog odgoja Teen STAR«, Obnovljeni život, 59 (4): 511-524.

Štulhofer, Aleksandar, Ajduković, Dean, Božičević, Ivana i Kufrin, Krešimir (2006). HIVIAIDS $i$ mladi - Hrvatska 2005. Zagreb: Ministarstvo zdravstva i socijalne skrbi.

Štulhofer, Aleksandar, Graham, Cynthia, Božičević, Ivana, Kufrin, Krešimir i Ajduković, Dean (2009). »An Assessment of HIV/STI Vulnerability and Related Sexual Risk-Taking in a Nationally Representative Sample of Young Croatian Adults«, Archives of Sexual Behavior, 38 (2): 209-225. doi:10.1007/s10508-0079234-8

Underhill, Kristen, Montgomery, Paul i Operario, Don (2007). »Sexual abstinence only programmes to prevent HIV infection in high income countries: systematic review«, British Medical Journal, http://www.bmj.com/content/early/2006/12/31/ bmj.39245.446586.BE (15. 02. 2010.). doi:10.1136/bmj.39245.446586.BE

UNESCO (2009). International Guidelines on Sexuality Education: An Evidence Informed Approach to Effective Sex, Relationships and HIV/STI Education. Paris: UNESCO.

Wellings, Kay i Parker, Rachel (2006). Sexuality Education in Europe: A Reference Guide to Policies and Practices. Brussels: IPPF Europen Network.

Wiederman, Michael W. (1999). »Volunteer Bias in Sexuality Research Using College Student Participants«, Journal of Sex Research, 36 (1): 59-66. doi:10.1080/00224499909551968 


\section{Attitudes towards Comprehensive School-based Sex Education in Croatian Schools: Results from a National Study of Youth}

Jegor MODRIĆ

Zagreb, Croatia

jegor.modric@gmail.com

Damir ŠOH

Department of Sociology, University Centre for Croatian Studies, University of Zagreb, Croatia

Aleksandar ŠTULHOFER

Department of Sociology, Faculty of Humanities and Social Sciences, University of Zagreb, Croatia

This paper assessed young people's attitudes toward the need for sex education in Croatian schools and about the preferred sex educators. In addition, we analysed levels of acceptance for 11 topics which are commonly found in comprehensive sex education programs. The study, originally intended to explore HIV-related knowledge, attitudes, and sexual risks, was carried out in February 2010 on a national probability sample of young adults aged $18-25(\mathrm{~N}=1005)$. A large majority of participants $(83.8 \%)$ supported the introduction of sex education in Croatian schools. Asked about their preferred sex educator, participants most often reported a doctor $(36.9 \%)$ and peer educator (23\%). None of the 11 topics, derived from the recently published UNESCO International Guidelines on Sexuality Education, was assessed as unimportant. STIs and the Modes of Protection, Sexual Harassment and Abuse, and Pregnancy and Parenthood were the topics perceived as most important. Overall, the mean assessment for all 11 topics was $3.26(\mathrm{SD}=0.46$; range $=1-4)$. Gender differences were noted in the acceptance of some topics, but the ranking of the three most important and three least important topics was not gender-specific. Importantly, only a few differences were found in the assessment of sex education topics between the most religious and least religious participants. Overall, findings suggest that a majority of young Croatian adults support a rather similar concept of school-based sex education.

Key words: sex education, comprehensive sex education, youth, schools, UNESCO guidelines for sex education, religiosity 